\title{
A New Educational Method to Acquire and Transfer Experience-based Wisdom for Power Engineers
}

\author{
Sumie Kyomoto Member (Mitsubishi Electric Corp.) \\ Atsushi Doi Member (Tokyo National College of Technology)
}

Keywords: experimental knowledge, tacit knowledge, explicit knowledge, know-how, knowledge science, educational system

Experience-based wisdom is a potent form of expertise built on specialized knowledge and skills, tacit knowledge and insights etc. Experimental knowledge and skills have been transferred through an apprentice system and on-the-job training (OJT). Electric power industry faces circumstances where advances in system automation technologies and enhancement of operational reliability make OJT opportunities less frequent and consequently it becomes difficult to rely simply on a traditional method based on OJT for successfully passing knowledge and skills from one generation of technicians to another. In addition, the "year 2007 issue" puts companies concerned at risk of losing sophisticated skills or know-how which veterans in their employment have accumulated over many years of service.

This paper discusses, in light of the usefulness of "guided experience" under the apprentice system, a training/education scheme designed to realize an inheritance of experienced personnel's knowhow, in particular tacit knowledge, and a new educational system which is based on this notion.

A system is proposed which involves: 1) making use of a work simulator, 2) accumulating tacit knowledge which experienced personnel use as the way or process to identify, analyze and solve complex problems in specific challenging situations, and 3) realizing "learning by doing" which is supported by the database of tacit knowledge. Trial on a prototype has proved the feasibility of this system.

The concept of the proposed system and required functions to develop experience-based wisdom are shown in Fig. 1 and Table 1 respectively. Conventional training facilities for power engineers, which feature simulation-based OJT, let a trainer pass down his experimental knowledge directly to trainees. This system, by contrast, permits inexperienced personnel to acquire such know-how from the system itself even if a trainer is non-existent time-wise or space-wise. This system is expected to enable a limited number of experienced people to train a large number of the less experienced as well as to assure storage and transfer of know-how obtained by preceding generations of employees.

The following are principal advantages which the system offers:

(1) Experienced personnel can help deposit know-how in the system without much concern about turning it into document form.

(2) Inexperienced personnel can acquire know-how empirically on the basis of "learning by doing" which is provided by the system.

(3) Passing experienced personnel's approach to problem solution without a means prepared in document form gives learners the chance to take over hidden know-how.

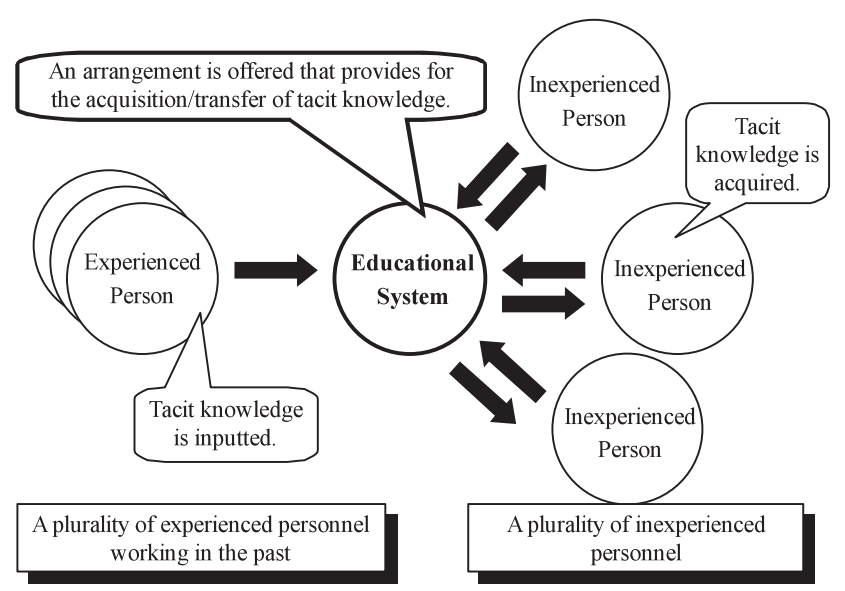

Fig. 1. The concept of the new system

Table 1. Required functions to develop experience-based wisdom

\begin{tabular}{|c|c|c|c|}
\hline \multirow[b]{2}{*}{ Learning modes } & \multirow[b]{2}{*}{ Learning processes } & \multicolumn{2}{|r|}{ Development of system functions } \\
\hline & & $\begin{array}{l}\text { Levels of learning goal } \\
\text { (training materials) }\end{array}$ & Primarily required functions \\
\hline \multirow{3}{*}{ Guided Practice } & $\begin{array}{l}\text { Practice under the supervision } \\
\text { of a knowledge coach }\end{array}$ & \multirow{3}{*}{$\begin{array}{l}\text { High-difficulty level } \\
\text { problems encountered in } \\
\text { the past and examples of } \\
\text { practiced solutions }\end{array}$} & $\begin{array}{l}\text { Function allowing learners to solve a problem by themselves according to a } \\
\text { procedure used by experienced personnel }\end{array}$ \\
\hline & \multirow{2}{*}{$\begin{array}{l}\text { Feedback to oneself which } \\
\text { results from teaching acquired } \\
\text { know-how to others }\end{array}$} & & Function which accumulates learner's own procedures which have been applied \\
\hline & & & Arrangement in which discussions are made on questions raised by others \\
\hline \multirow{4}{*}{ Guided Observation } & $\begin{array}{l}\text { Observing knowledge coach's } \\
\text { approach }\end{array}$ & \multirow{4}{*}{$\begin{array}{l}\text { Solution process for } \\
\text { high-difficulty level } \\
\text { problems encountered in } \\
\text { the past }\end{array}$} & $\begin{array}{l}\text { Function which permits observing problem-solving processes used by experienced } \\
\text { personnel }\end{array}$ \\
\hline & \multirow{3}{*}{$\begin{array}{l}\text { Feedback which results from } \\
\text { discussing observation results } \\
\text { with a knowledge coach }\end{array}$} & & $\begin{array}{l}\text { Function allowing learners to solve a problem by themselves and to receive } \\
\text { check/guidance in regard to difference between problem-solving process of their } \\
\text { own and the one used by experienced personnel }\end{array}$ \\
\hline & & & $\begin{array}{l}\text { Arrangement in which learners ask experienced personnel questions about what } \\
\text { they find uncertain and have a discussion for clarification }\end{array}$ \\
\hline & & & Arrangement in which relevant material can be searched for information desired \\
\hline \multirow{2}{*}{$\begin{array}{c}\text { Guided Problem } \\
\text { Solving }\end{array}$} & \multirow[t]{2}{*}{$\begin{array}{l}\text { Tackling a problem together } \\
\text { with a knowledge coach }\end{array}$} & \multirow{2}{*}{$\begin{array}{l}\text { Mainly, high-difficulty } \\
\text { level problems expected } \\
\text { in the future and } \\
\text { examples of solutions }\end{array}$} & $\begin{array}{l}\text { Function allowing learners to solve a problem by themselves and to obtain useful } \\
\text { information in regard to difference between problem-solving process of their own } \\
\text { and the one used by experienced personnel }\end{array}$ \\
\hline & & & Arrangement for discussions with others and search into relevant material \\
\hline
\end{tabular}




\title{
熟練ノウハウの継承を目指した電力技術者教育方式の システム化検討
}

\author{
正 員 京本寿美恵* 正 員 土井 淳**
}

\author{
A New Educational Method to Acquire and Transfer Experience-based Wisdom \\ for Power Engineers \\ Sumie Kyomoto*, Member, Atsushi Doi**, Member
}

\begin{abstract}
Electric power industry faces circumstances where advances in system automation technologies and enhancement of operational reliability make on-the-job training (OJT) opportunities less frequent and consequently it becomes difficult to rely simply on a traditional method based on OJT for successfully passing experimental knowledge and skills from one generation of technicians to another. In addition, the "year 2007 issue" puts companies concerned at risk of losing sophisticated skills or know-how which veterans in their employment have accumulated over many years of service.

This paper discusses, in light of the usefulness of "guided experience" under an apprentice system, a training/education scheme designed to realize an inheritance of experienced personnel's know-how, in particular tacit knowledge, and a new educational system which is based on this notion. A system is proposed which involves: 1) making use of a work simulator, 2) accumulating tacit knowledge which experienced personnel use as the way or process to identify, analyze and solve complex problems in specific challenging situations, and 3) realizing "learning by doing" which is supported by the database of tacit knowledge. Trial on a prototype has proved the feasibility of this system.
\end{abstract}

キーワード : 経験知, 暗黙知, 形式知, ノウハウ, 知識科学, 教育システム

Keywords: experimental knowledge, tacit knowledge, explicit knowledge, know-how, knowledge science, educational system

\section{1. はじめに}

近年，我が国では「科学技術離れ」「理科離れ」が大きな 社会問題となっており，科学技術創造立国の実現に向け，科 学技術関係の人材の質と量の確保が重要な課題となってい る。また，電力分野においては，昨今急激な発展を遂げて いる情報通信分野に比べた相対的な魅力の低下の懸念があ

り，人材確保の対策が強く望まれている。

一方，電力技術者の教育訓練においては，各種システム の自動化や高信頼度化によるトラブル遭遇機会・保守機会 の減少により，従来これらの経験を通じて習得していた知 識・技術が伝承しにくい環境になっている(1)。

加えて, 約 670 万人を数える「団塊世代」が一斉に退職

\footnotetext{
* 三菱電機 $($ 株 $)$ 系統変電システム製作所

厂 651-2271 神戸市西区高塚台 1-5-8

Mitsubishi Electric Corporation

1-5-8, Takatsukadai, Nishi-ku, Kobe 651-2271

** 東京工業高等専門学校 電気工学科

干 193-0997 八王子市椚田町 1220-2

Tokyo National College of Technology

1220-2, Kunugida-machi, Hachioji 193-0997
}

することにより企業活動に大きなダメージを与えるとされ る，「2007 年問題」が指摘されている(2)。2006 年版「もの づくり白書」(3)によれば, 2007 年問題に対する危機意識を 持つ企業は, 全産業で $33.7 \%$, 製造業では $41.1 \%$ にる。 この 2007 年問題における指摘の一つは,「ノウハウ・技術 継承の危機」であり, 特に危機意識の高い業種の $90 \%$ 近く が問題点として深刻にとらえている。ここでは，大量の熟 練技術者の退職に伴い, それまで培ってきた高度な技術 · ノウハウが企業から失われてしまうことが危惧されていて, これは, 経験から得られるいわゆる「暗黙知」についても 同様である。各企業は様々な方法でこの対策に取り組んで いるものの, 人材や時間の不足, 教える側と教えられる側 のレベルギャップ等により困難を極めているというのが現 状である。

このような情勢から，技術者教育を取り巻く状況におけ る重要な問題の一つである「人材力, 技術の担い手, 技術 伝承への危機感」(4)への対策として，限られた人材により 技術・ノウハウの蓄積と継承を円滑に進められる工夫が必 要となる。これを実現する方法の一つにコンピュータの活 用があり，これまで，ノウハウを知識データベース化する 
試みがいくつか進んでいる。しかし，熟練者が経験により 体得した暗黙知（経験知）は明確化して伝承することが困 難であり，これまでの試みは十分ではないと考えられる。

暗黙知は，古来より，徒弟制という形を通じた，指導の 下での体験により伝承されてきた。例えば，企業において は，指導者の下で実業務の多様な経験 (OJT) を繰り返すこ とにより，創造性が発揮できる知識として伝承されている。

本稿では，徒弟制によるところの「指導の下での体験」の 有用性を鑑み，熟練者のノウハウ，特に，暗黙知を伝承す るための教育 (学習) 支援方法と，これに基づく新しい教 育システムを論じる。教育対象業務のシミュレータを活用 することにより, 特殊条件下での複雑な検討が必要な個々 の問題の解決のノウハウを, 熟練者のアプローチの方法や 手順として蓄積し，それらが蓄積された暗黙知データベー スの下で「実践による学習」を行える新たな方式を提案す る。また，実際の業務を想定したプロトタイプにより，そ の実現性を検証する。

\section{2. ノウハウの継承と学習}

$\langle\mathbf{2 \cdot 1 \rangle}$ 経験による知識 知識科学の分野において,「暗 黑知」とは, 言語・図表・数式などで表現できない身体的な 知であると定義され，経験を通して獲得されるため「経験 知」とも言い換えられる。暗黙知と対比されるのは「形式 知」であり，これは言語などで説明できる知識である。熟 練者のもつノウハウとは，形式知と暗黙知を含めた総合的 知識や判断力・洞察力を駆使して想定外の事象に遭遇して も適切に対処できる能力である，と考えることができ，， ウハウ継承の鍵は暗黑知の継承にあると言える。

$\langle\mathbf{2} \cdot \mathbf{2}\rangle$ 暗黙知の継承と学習 暗黙知の継承について は種々の議論がなされている(5)。文献(5)でも論じられて いるSECI モデルによれば，「暗黙知を言語化して形式知に 変換し，共有可能にされた，あるいは，新たに創造された 形式知は，そのままでは個人が活用することができないこ とがある」「個人が外部から取り入れた形式知を活用するた めには，自分の中でその知識を消化し，暗黙知として自分 の身につけるプロセスが必要」とされる。また，最近の新 しい着眼点として,「初心者が経験知を獲得するには, 習得
過程に付き添って指導し続けるコーチの存在が不可欠」と されている。また，レオナルドら (6)は，「暗黙知/経験知を 得るために必要なことは経験，特に，ナレッジ・コーチの “指導の下での体験”によって継承が可能」とし，暗黙知継 承への推移モデルを提唱している。

表 1 にレオナルドらの示す, 暗黙知継承への推移モデル （以下，「推移モデル」）を示す。暗黙知の継承には，表に示 すとおり，「実践による学習」が不可欠であるとされている。 このうち,「指導の下での実践」の学習モデルは,「反省を 指導し, 成果についてフィードバックできる人の監督の下 で実践を繰り返すこと」とされ，「指導の下での観察」は， 「ベテランに張り付かせること (観察) とフィードバックす ること（観察したことについての議論）の組み合わせ」と される。また,「指導の下での問題解決」は，「教える側も 共に問題と格闘し, 教えられる側はいかに問題にアプロー チすべきかを学ぶ。ナレッジ・コーチは知識よりも実践方 法を伝授する。とされている。

電力会社に抢ける技術者教育形態の過去の調査事例 (1) を これらのモデルに対応させたものを表 2 に示す。社内の研 修の他，社内上位技術者やメーカとのOJTなどを通じ，「実 践による学習」が網羅されていて, このモデルは従来の教 育訓練方法とよく合った現実的なものであると言える。

以上の議論をもとに，ここでは，熟練者のノウハウの継 承を円滑に進めるため，推移モデルの「指導の下での実践」 から「指導の下での問題解決」までをトータルにデザイン

表 1 暗黙知継承への推移モデル (6)

Table 1. The model to transfer tacit knowledge.

\begin{tabular}{|c|c|c|}
\hline & & Learning modes \\
\hline \multirow{3}{*}{\multicolumn{2}{|c|}{ Passive Perception }} & Rules of Thumb \\
\hline & & Stories with a Moral \\
\hline & & Socratic Questioning \\
\hline & \multirow{4}{*}{$\begin{array}{l}\text { Learning } \\
\text { by Doing }\end{array}$} & Guided Practice \\
\hline & & Guided Observation \\
\hline & & Guided Problem Solving \\
\hline Active Learning & & Guided Experimentation \\
\hline
\end{tabular}

表 2 電力会社における技術者教育形態の例

Table 2. An example of training methods in electric power companies.

\begin{tabular}{|c|c|c|c|}
\hline Learning modes & Teaching patterns for entry-level engineers & \multicolumn{1}{|c|}{ Teaching patterns for intermediate-level engineers } \\
\hline Guided Practice & $-\quad \begin{array}{l}\text { Training or guidance given by expert engineers through } \\
\text { routine work }\end{array}$ & $\begin{array}{l}\text { Training or guidance given to entry-level engineers through } \\
\text { routine work } \\
\text { Collective training intended for engineers who are involved in } \\
\text { such activities as planning, design, operations, construction, or } \\
\text { maintenance }\end{array}$ \\
\hline Guided Observation & $-\quad \begin{array}{l}\text { A briefing after the installation of equipment and/or factory } \\
\text { witness testing } \\
\text { A meeting with a supplier to discuss specifications }\end{array}$ & - Joint research and/or development effort with a manufacturer \\
\hline Guided Problem & $-\quad \begin{array}{l}\text { A directly-run course at a training facility under the guidance of } \\
\text { higher-ranking personnel }\end{array}$ & $\begin{array}{l}\text { A briefing after the installation of equipment and/or factory } \\
\text { witness testing } \\
\text { A meeting with a supplier to discuss specifications } \\
\text { A directly-run course at a training facility under the guidance of } \\
\text { higher-ranking personnel }\end{array}$ \\
\hline
\end{tabular}


し，システム化することを試みる。

\section{3. 電力技術者教育システム}

$\langle\mathbf{3} \cdot \mathbf{1}\rangle$ システムの要件 今後求められる技術者教育 システムは, 従来社内外の OJT を通じて得ていた暗黙知 を，少数の熟練者と少ない実務経験の環境下で得ることを 可能とするシステムである。OJTによる学習は, 様々な問 題における熟練者の模倣・観察や熟練者によるチェックを 通じ，未熟練者が無意識のうちに暗黙知を獲得するもので あり，このしくみをシステム化することが有効である。

電力分野における，模擬 OJT による教育訓練設備の代表 的なものとして, 系統操作やプラント運転などの訓練シミュ レータが上げられる。これらは，トレーナの設定した訓練 シナリオを用いて，トレーナの指導の下でトレーニが訓練 を受けることを想定して構築されており，暗黙知は熟練者 であるトレーナから未熟練者であるトレーニに直接伝承さ れる。

提案するシステムは，熟練者の減少という環境の中，熟 練者と未熟練者が時間的または空間的に共存していなくて も，未熟練者への暗黙知伝承を可能とするもので，前述の 知識科学的議論と背景状況から導き出されるシステムの要 件は，以下の通りである。

（1）「推移モデル」における，「指導の下での実践」，「指 導の下での観察」，「指導の下での問題解決」を経験 するプロセスの実現

（2）ナレッジ・コーチ（トレーナ）の役割を為すもの の実現

（3）少数熟練者で多数の未熟練者を教育できること

（4）過去の複数の熟練者が持つ暗黙知を蓄積し，これ らを用いて学習できること

これらの要件を実現するシステムの概念図を図 1 に示す。 熟練者は何らかの手段で暗黙知をシステムに入力し，未熟 練者は何らかの手段で暗黙知を習得する。システムは，熟 練者からの暗黙知獲得と未熟練者への伝承を行い, 未熟練 者に対してのナレッジ・コーチの役割を為す。これにより， 従来, 熟練者と未熟練者の間で行われていた OJTを，シス テムと未熟練者の間で模擬的に実現できることになる。

$\langle 3 \cdot 2\rangle$ 構成要素 図 2 にシステムの構成要素を示す。 基本的な要素は, 対象業務のシミュレータ, 業務シミュレー 夕を用いて熟練者や学習者が問題を解決するアプローチを 記録する収集蓄積機能，履歴データ，熟練者のアプローチ を履歴データから再現する復元機能, 及び, 学習者のアプ ローチを熟練者のアプローチと比較するための比較・判定 機能である。

ここで業務シミュレータとは，任意の教育対象業務にお いて, 教育対象業務を模擬的に実施することを可能とするも のである。業務支援システム及び業務対象物のシミュレー 夕がこれに相当する。例えば, 電力系統解析・運用・計画

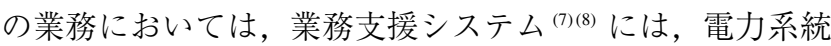
解析支援システムや保護リレー整定支援システム，需給計

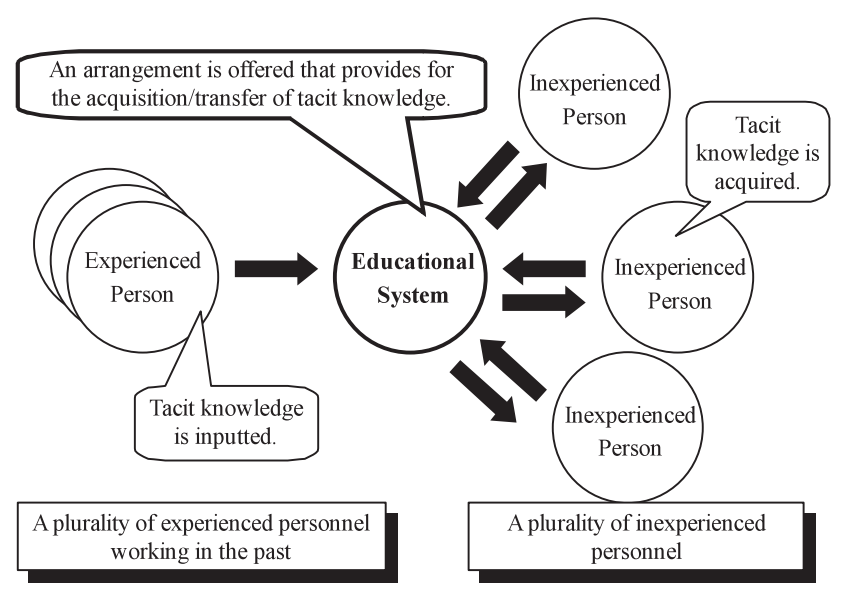

図 1 教育システムの概念図

Fig. 1. The concept of the new system.

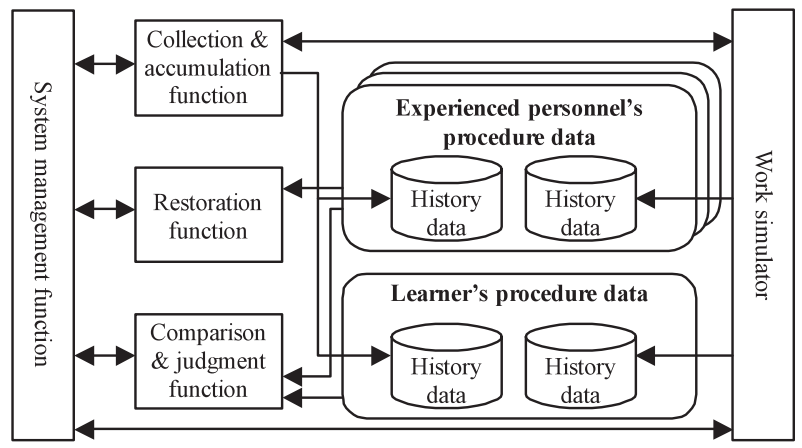

図 2 システムの構成要素

Fig. 2. Basic elements of the system.

画システムなどがある。また，業務対象物のシミュレータ には，各種の電力系統解析プログラムなどがある。この業 務シミュレータは複数存在してもかまわない。

これらの基本要素を組み合わせることにより，システム は, 熟練者のノウハウを獲得・蓄積し, それを学習者へ伝 承することが可能となる。以下，その具体的方法を述べる。

$\langle\mathbf{3} \cdot \mathbf{3}\rangle /$ ノハウ獲得のための機能 $\langle 2 \cdot 1\rangle$ 節に述べた ように，熟練者の暗黙知は，明示的に表現することが困難 である。このため, ある業務課題に対して熟練者が業務シ ミュレータを用いた模擬的な解決を行う過程で, システム が履歴データとして熟練者のノウハウを獲得する。

ここで，履歴データは，ある業務課題に対する業務実施 者の解決のアプローチを, 操作手順, 業務手順, 実施事項等 を示すデータの形で保存したものである。「業務手順，実施 事項等」とは, 例えば, 前述の電力系統解析業務を例にす ると，どのような条件でどのような解析をどのような順序 で実施したか, また, 解析の結果のどのような点をどのよ うなデータで確認したか, 確認の結果, どのような処置を 施したか，などにあたる。つまり，履歴デー夕を構成する データ全体には，暗黙的に当該操作者の業務への取り組み の方法や課題解決のノウハウが反映されていることとなる。 
表 3 ノウハウ伝承のための機能要件

Table 3. Required functions to develop experience-based wisdom.

\begin{tabular}{|c|c|c|c|}
\hline \multirow[b]{2}{*}{ Learning modes } & \multirow{2}{*}{ Learning processes ${ }^{(6)}$} & \multicolumn{2}{|r|}{ Development of system functions } \\
\hline & & $\begin{array}{l}\text { Levels of learning goal } \\
\text { (training materials) }\end{array}$ & Primarily required functions \\
\hline \multirow{3}{*}{ Guided Practice } & $\begin{array}{l}\text { Practice under the supervision of a } \\
\text { knowledge coach }\end{array}$ & \multirow{3}{*}{$\begin{array}{l}\text { High-difficulty level } \\
\text { problems encountered in } \\
\text { the past and examples of } \\
\text { practiced solutions }\end{array}$} & $\begin{array}{l}\text { Function allowing learners to solve a problem by themselves according to } \\
\text { a procedure used by experienced personnel }\end{array}$ \\
\hline & \multirow{2}{*}{$\begin{array}{l}\text { Feedback to oneself which results } \\
\text { from teaching acquired know-how } \\
\text { to others }\end{array}$} & & $\begin{array}{l}\text { Function which accumulates learner's own procedures which have been } \\
\text { applied }\end{array}$ \\
\hline & & & Arrangement in which discussions are made on questions raised by others \\
\hline \multirow{4}{*}{ Guided Observation } & $\begin{array}{l}\text { Observing knowledge coach's } \\
\text { approach }\end{array}$ & \multirow{4}{*}{$\begin{array}{l}\text { Solution process for } \\
\text { high-difficulty level } \\
\text { problems encountered in } \\
\text { the past }\end{array}$} & $\begin{array}{l}\text { Function which permits observing problem-solving processes used by } \\
\text { experienced personnel }\end{array}$ \\
\hline & \multirow{3}{*}{$\begin{array}{l}\text { Feedback which results from } \\
\text { discussing observation results with } \\
\text { a knowledge coach }\end{array}$} & & $\begin{array}{l}\text { Function allowing learners to solve a problem by themselves and to } \\
\text { receive check/guidance in regard to difference between problem-solving } \\
\text { process of their own and the one used by experienced personnel }\end{array}$ \\
\hline & & & $\begin{array}{l}\text { Arrangement in which learners ask experienced personnel questions } \\
\text { about what they find uncertain and have a discussion for clarification }\end{array}$ \\
\hline & & & $\begin{array}{l}\text { Arrangement in which relevant material can be searched for information } \\
\text { desired }\end{array}$ \\
\hline \multirow[t]{2}{*}{$\begin{array}{l}\text { Guided Problem } \\
\text { Solving }\end{array}$} & \multirow[t]{2}{*}{$\begin{array}{l}\text { Tackling a problem together with a } \\
\text { knowledge coach }\end{array}$} & \multirow{2}{*}{$\begin{array}{l}\text { Mainly, high-difficulty } \\
\text { level problems expected in } \\
\text { the future and examples of } \\
\text { solutions }\end{array}$} & $\begin{array}{l}\text { Function allowing learners to solve a problem by themselves and to } \\
\text { obtain useful information in regard to difference between } \\
\text { problem-solving process of their own and the one used by experienced } \\
\text { personnel }\end{array}$ \\
\hline & & & Arrangement for discussions with others and search into relevant material \\
\hline
\end{tabular}

この履歴データは, 収集蓄積機能と業務シミュレータの 両方により蓄積される。収集蓄積機能は, 業務シミュレー 夕の動作や入出力を常時監視し, 得られた情報を履歴デー 夕として蓄積する。業務シミュレータを複数用いる業務の 場合は，全ての業務シミュレータを監視し，これらの使わ れ方の前後関係も蓄積する必要がある。業務シミュレー夕 は，これを補完する情報として，各業務の教育に必要な固 有情報を，動作ログなどにより履歴データとして蓄積する。

本機能により, 熟練者は, 特別に意識をすることなく, 業 務シミュレータを用いて模擬的に課題解決に当たることに より, 解決のノウハウをシステムに蓄積することが可能と なる。訓練シミュレータの訓練シナリオ設定や, 近年試み られている，熟練者の業務手順のマニュアル化などにおい ては，熟練者（トレーナ）の負担増が懸念されているが，本 機能により，教育における熟練者の負担の軽減という点で の改善効果も得られる。

$\langle\mathbf{3} \cdot \mathbf{4}\rangle$ ノウハウ伝承のための機能 〈2·2 節に述べた ように, 効果的なノウハウの習得は, 模擬 OJT を通じ，「推 移モデル」に示される「指導の下での実践」，「指導の下での 観察」,「指導の下での問題解決」のプロセスを経験すること により実現可能であると考えられる。そこで，これらの各 学習形態における学習プロセスと, これを支援するために

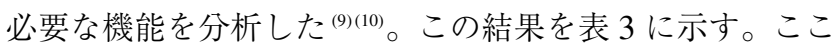
に示す通り，学習者自身が熟練者の実施手順に従って課題 解決を模擬的に実施する機能, 熟練者の解決プロセスを観 察する機能，及び，熟練者の解決プロセスとの比較チェッ ク・学習者へのガイダンス提示機能がノウハウ伝承のため の必須機能として上げられる。

これらの機能は, 図 2 に示す収集蓄積機能, 復元機能, 比較・判定機能を組み合わせることにより実現する。収集 蓄積機能は, 学習者が業務シミュレータを用いて業務課題 に取り組む履歴を履歴データとして蓄積し，比較・判定機
能は, 熟練者の履歴デー夕と学習者の履歴デー夕を比較し, 学習者の取り組みが適切か否かを判定する。復元機能は, 熟練者の取り組みを復元するものである。

比較・判定は, 熟練者と学習者の履歴データの完全一致 を判定するものではない。業務課題解決の過程で必ず一致 すべき点とそうでない点があるため，これに基づき判定基 準を設定する。主要な基準は, 業務手順の適否, 入力デー 夕の適否, 結果の正誤, 要実施事項の過不足などである。

以上の基本要素を組み合わせることにより, 様々な形態 の学習が可能となる。例えば, 学習者が業務課題に取り組 む過程の適当なタイミングで比較・判定処理を行うことに より, 熟練者の実施手順に沿った取り組みをガイドする, 即 ちナレッジ・コーチの監督の下で課題解決に取り組む状況 を模擬することができる。また, 学習者が業務課題を解決 した後に取り組みの適不適を総合的に判定することで，反 省・試行錯誤による学習が可能となる。そして，復元機能 を用いて熟練者の様々な取り組みを観察させることにより, 個別ケースに依存しないより深いノウハウについても熟考 を促すことができる。

本機能によれば, 熟練者がその場にいなくても, システ ムに蓄積された熟練者の履歴データから，様々な形態での 学習が可能であり, 未熟練者の学習機会の自由度が増える という効果も得られる。

\section{4. プロトタイプによる実現性の検証}

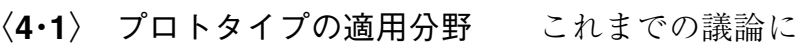
基づき，実際の業務を想定したプロトタイプを開発するこ とにより，システムの実現性を検証する。ここでは，その 適用分野として, 保護リレー運用技術者の教育に着目し，リ レー整定検討技術を教育対象技術とする。

リレーの整定検討は，リレーの事故検出感度，動作時限 の適正な值を決定する業務であり，種々の解析計算，整定 


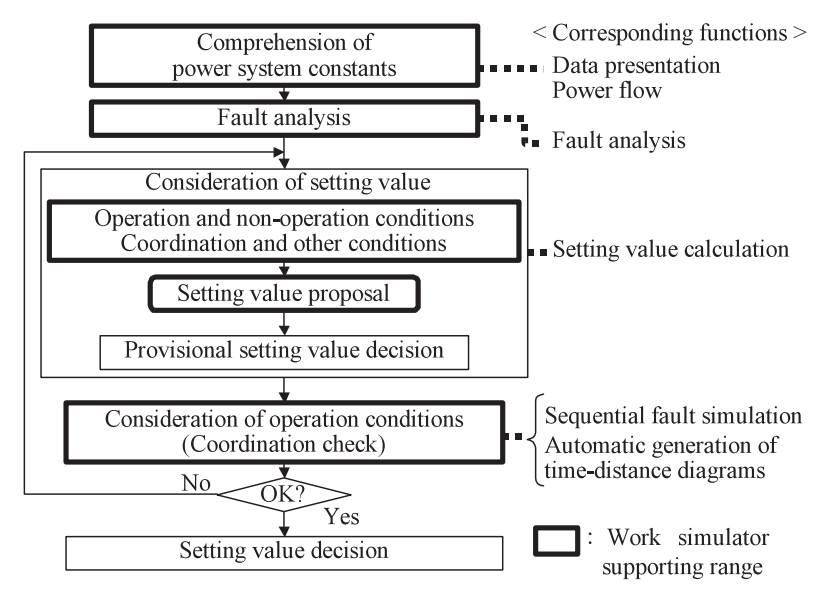

図 3 適用対象業務と業務シミュレータの機能

Fig. 3. The application area of the prototype.

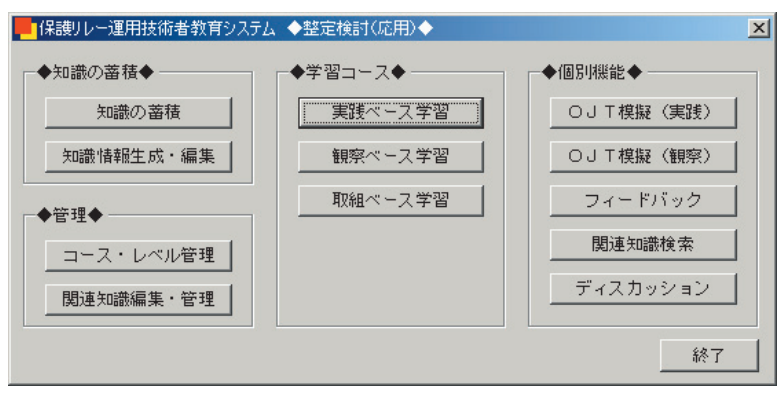

図 4 システムのメニュー画面

Fig. 4. The menu screen of the prototype.

計算及びリレーの動作協調の綿密な検討を必要とする複雑 な業務であると共に，ノウハウが要求される高度な業務で ある。図 3 に整定検討業務フローの一例を示す。本プロト タイプでは，業務シミュレータとして，図中に示す機能を 持つ整定検討システムを作成し，使用している。

〈4·2〉 システムの全体機能システムのメニュー画 面を図 4 に示す。主機能として, 以下の機能を実装した。

（1）「知識の蓄積」機能熟練者のノウハウ獲得のた めの機能で，熟練者が整定検討システムを用いて整定検討 を実施する履歴を履歴データとしてシステム内に蓄積する 機能 (「知識の蓄積」) と，ノウハウ伝承機能にて用いる，比 較・判定の基準やガイドメッセージの編集を行う機能（「知 識情報生成・編集」）を持つ。

（2）「学習コース」機能未熟練者へのノウハウ伝 承のための機能として, 推移モデルの学習形態に対応する 学習を可能とする。

システム実現の鍵は, 表 3 に示すノウハウ伝承機能の効 果的な具現化にある。以下，「学習コース」の 3 つの機能と 期待する効果について述べる。

〈4·3〉実践ベース学習本機能は, 表 3 における「指 導の下での実践」を実現するものである。学習者が整定検 討システムを用いて課題を解決する過程の各操作ステップ

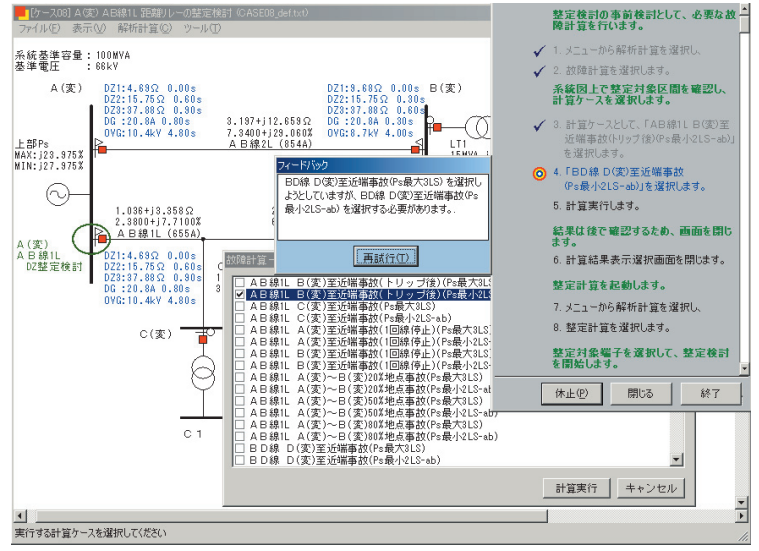

図 5 実践ベース学習の画面例

Fig. 5. An example of the Guided Practice mode.

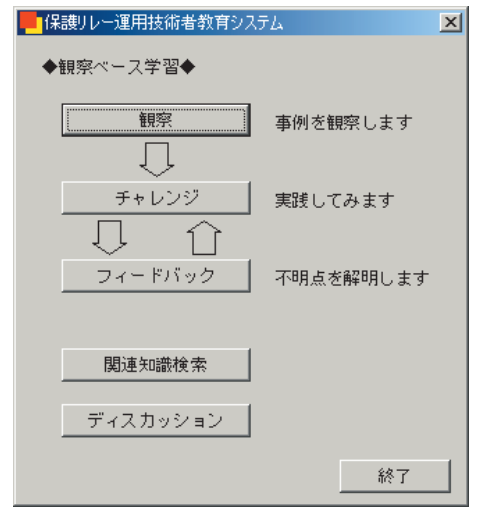

図 6 観察ベース学習の機能

Fig. 6. Functions of the Guided Observation mode.

で, システムが学習者の課題解決手順と熟練者の履歴デー 夕を比較する。図 5 に実践ベース学習中の画面例を示す。 両者の手順が一致しない場合はエラーとし，エラー内容を 示すガイドメッセージ（画面中央）や熟練者の手順（画面 右方）を提示することにより，熟練者の解決手順と同様の 方法で課題解決を行うよう導く。

これにより，ナレッジ・コーチに逐一指導を受けながら， ステップバイステップで, 必要な検討事項と, 各実施事項 の意味を学び, 課題解決の一方法を身につける, という状 況を模擬することができる。

〈4・4〉観察ベース学習本機能は, 表 3 の「指導の下 での観察」を模擬するもので，図 6 に示すとおり，「観察」, 「チャレンジ」，「フィードバック」の組み合わせから成る。 まず，「観察」機能では，システムが熟練者の履歴デー夕 を復元することにより，熟練者が整定検討システムを用い て整定検討を行う手順を動画で再現する。学習者は, 熟練 者の取り組みを観察することにより, 課題解決の一連の流 れを学ぶ。また，単一のケース（課題）の観察ではノウハ ウの習得が困難な場合でも，複数の類似ケースを観察する ことにより，それらに共通的に存在するノウハウを習得す 
ることが可能となる場合がある。このことを考慮し, 複数 のケースの観察も行える機能とした。

次に, 学習者は「チャレンジ」機能により模擬実践を行 う。本機能では, 学習者が整定検討システムを用いて課題 を解決する過程をシステムが熟練者の履歴デー夕と比較す るが，以下の点で実践べース学習との違いを持たせた。第 一に, 課題解決手順判定の制約を緩め, 操作に自由度を持 たせることで，学習者の能動的な取り組みと熟考を促す。 例えば，細かい手順が前後したり，必須でない部分の省略 があったりした場合でも必要な事項ができていれば良と判 定される。第二に, 不適切と判断される操作を行った場合, システムは不適切である旨のみを示し，答えを提示しない ことにより，学習者に考えさせる。

ここでは, 学習者は「観察」の過程で得たノウハウを実 践することにより確認し，潜在的な不明点を明らかにする。 また，熟練者と異なる方法を試みることにより，多様な解 決方法を習得し，自己のノウハウとしての定着を眓る。

「フィードバック」機能は,「チャレンジ」機能で不明点が あった場合に，当該部分についての再確認を行う機能と位 置付ける。学習者は, 当該部分についてガイダンスに沿つ た操作を行い, システムは学習者の操作を熟練者の手順と 比較する。これらの間に違いが検出された場合は, 熟練者 の手順が部分的に再現される。これにより，不明点を絞り 込んでナレッジ・コーチに確認し, 詳細な指導を得ること により，理解を深める過程が模擬できる。

$\langle\mathbf{4} \cdot \mathbf{5}\rangle$ 取組ベース学習 本機能は, 表 3 に㧍ける「指 導の下での問題解決」を模擬するものである。この段階で は, ナレッジ・コーチにも正しい課題解決方法がわからな い場合がある状況 (6) を想定することから, 取組べース学習 の目標レベルは，将来の高難易度問題とする。

この段階では，学習者が未知の課題に自主的かつ積極的 に取り組むことにより経験の幅を広げ，試行錯誤を通じて ノウハウを強化し，ナレッジ・コーチの取り組みを参考に しながら，自己の取り組みを見直すことを期待する。また， 自分自身の失敗経験を反省するだけでなく,ナレッジ・コー チの失敗を他山の石とし，自己のノウハウを磨くことも期 待される。

これらを前提とし，本機能では，学習者は何ら制約を受 けることなく整定検討システムを利用し, 課題解決にあた る。学習者が課題解決を終了した後, システムが学習者の 履歴デー夕と熟練者の履歴デー夕を比較し, 解決プロセス の相違を参考情報として提供する。

$\langle\mathbf{4 \cdot 6 \rangle}$ 推移モデルのシステム化検証 本プロトタイ プにより, 距離リレーの整定検討の課題を想定し, システ ムの実現性を確認した。想定する熟練者の手順を「知識の 蓄積」機能を用いて蓄積し，この熟練者の履歴デー夕によ り, 各学習機能が実現できることを検証した。学習者の履 歴デー夕と熟練者の履歴デー夕の比較・判定項目として, 図 3 に示すフロー中の, 故障計算や協調チェック（リレー 応動シミュレーション，短絡協調図によるチェック）の実
施ケース・結果確認項目の過不足や, 整定計算の入力デー 夕の妥当性, 業務手順などを設定し, 実践ベース学習, 観 察べース学習, 取組ベース学習で判定方法を変化させるこ とで, 〈4·3〉節〜〈4.5〉節に述べた機能を実現した。図 5 は, 実践ベース学習で, 故障計算の実施ケースの設定に誤 りがあると判定された画面の例である。

実際の OJT に拈いては，熟練者が未熟練者に指導をする 場合，レベルに応じて指導方法を変化させることが行われ るが, 本プロトタイプでも実践ベース学習, 観察ベース学 習, 取組ベース学習で比較・判定の方法と不適切時の応答 の方法に変化を持たせることにより，実際の OJT に近い状 況を模擬できる。前述の 3 つの学習ステップを踏むことに より, 推移モデルに示される実践による学習を模擬的に行 うことができ, 熟練者のノウハウ習得と自己のノウハウ醸 成が可能となると考えられる。

なお，学習者の履歴デー夕と熟練者の履歴デー夕の比較. 判定のための基準は,「知識情報生成・編集」機能により編 集できる。主要項目は, 各手順の判定要否, 判定方法 (值 の比較判定, 実施有無判定など), 不適切と判定された場合 のメッセージの内容などである。システムは熟練者の履歴 データから, 課題解決手順の全ステップの生成と, 各ステッ プに対する上記項目の設定を行い, 熟練者が必要に応じて 編集を行うことができる。

\section{5. まとめ}

本論文では，熟練者のノウハウ伝承の鍵となる暗黙知の 伝承について, 徒弟制によるところの「指導の下での体験」 の有用性に着目し, 効果的な継承・学習方法を考察してい る。また，この考え方に基づく電力技術者教育システムを 提案し，プロトタイプにより実現性を検証している。本シ ステムの特長と期待される効果は以下の通りである。

（1）熟練者は業務シミュレー夕を用いた模擬的な課題 解決を行うことにより, 知識の明文化を意識することなく, ノウハウをシステムに蓄積することができる。

（2）未熟練者はシステムを用いた模擬 OJT を通じて, 実務との親和性が良い形で知識・ノウハウを体得できる。

（3）熟練者の取り組みをそのまま未熟練者に伝えるこ とにより, 熟練者が意識していないノウハウについても, 未 熟練者が吸い上げることができる。

（4）観察と実践を組み合わせた能動的かつ体験型の学 習により, 失敗・熟考・反省を通じた, 応用力, 考える力 の䁔成に寄与する。

熟練者の減少や OJT の機会の減少という環境の中, 知識・ 技術の伝承は今後ますます重要な課題となる。本システム の実現により，少数の熟練者による多数の未熟練者の教育 が可能となるばかりでなく, 過去の熟練者のノウハウの蓄 積と継承が期待できる。今後, 比較・判定機能への柔軟性 の付加, 形式知データとの組み合わせにより学習効果を高 める工夫など，実用化に向けて更なる検討を進める。

(平成 19 年 2 月 24 日受付, 平成 19 年 6 月 1 日再受付) 


\section{文献}

（1）保護リレーシステム工学の体系化調查専門委員会:「保護リレーシス テム工学の体系化と技術者育成」, 電気学会技術報告, No.717 (1999-2)

（2）経産省・厚労省・文科省：2005 年版ものづくり白書 (製造基盤白書) (2005-6)

（3）経産省・厚労省・文科省：2006 年版ものづくり白書 (2006-6)

(4) M. Yoshida: “Towards Innovative Engineering Education", IEEJ Journal, Vol.125, No.10, pp.621-624 (2005-10) (in Japanese) 吉田 眞:「技術者教育を取り巻く状況について」, 電学誌, 125, 10, pp.621-624 (2005-10)

（5） 杉山公造・永田晃也・下嶋 篤：ナレッジサイエンス, pp.16-19, pp.8085, 紀伊国屋書店 (2002-12)

(6) D. Leonard and W. Swap: "Deep Smarts", Harvard Business Rev., Vol.30, No.2, pp.157-169 (2005-2) (in Japanese)

ドロシーレオナルド・ウォルタースワップ:「ディープ・スマート： 暗黙知の継承」, Harvard Business Review（日本語版), 30, 2, pp.157-169 (2005-2)

（7）土井 淳 ・清水恒夫 - 京本寿美恵：「電力系統運用業務支援システ 厶」, 三菱電機技報, Vol.70, No.4, pp.17-23 (1996-4)

（8）系統運用業務支援システム調查専門委員会：「系統運用業務支援シ ステム」, 電気学会技術報告, No.642 (1997-7)

(9) S. Kyomoto and A. Doi: "The Concept of a New Educational System to Acquire and Transfer Experience-based Wisdom", The Papers of Technical Meeting on Frontiers in Education, IEE Japan, FIE-06-12, pp.57-61 (20063) (in Japanese)

京本寿美恵・土井 淳：「熟練ノウハウ継承型技術者教育システム の検討一開発構想一」, 電気学会教育フロンティア研資, FIE-06-12, pp.57-61 (2006-3)

(10) S. Kyomoto and A. Doi: "Development of a New Educational System to Acquire and Transfer Experience-based Wisdom”, Proc. of the Seventeenth
Annual Conference of Power \& Energy Society, IEE Japan, 423, pp.44-2544-26 (2006-9) (in Japanese)

京本寿美恵・土井 淳 :「新・電力技術者教育システム一熟練ノウ 八ウの継承一」, 平成 18 年電気学会電力・エネルギー部門大会, 423 , pp.44-25-44-26 (2006-9)

京 本 寿美恵 (正員) 1964 年 10 月 11 日生。1987 年 3 月神戸

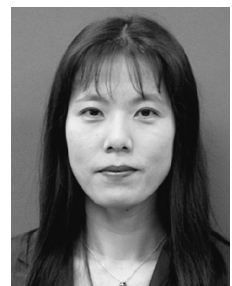
大学理学部卒業。同年 4 月三菱電機（株）入社。 現在，系統変電システム製作所に勤務。主として 系統・配電分野の業務支援システム, 保護制御シ ステムに関する業務に従事。

土 井淳 (正員) 1952 年 7 月 7 日生。1977 年 3 月早稲田

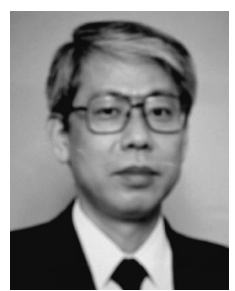
大学大学院理工学研究科電気工学専攻修士課程修 了。同年 4 月三菱電機（株）入社。2005 年 4 月 東京工業高等専門学校教授, 現在に至る。電力 · エネルギーシステムの解析・制御・計画に関する 研究に従事。工学博士。IEEE, エネルギー・資源 学会会員。 